\title{
MAPPING BORON AND BENEFICIAL HEAVY METAL IONS FOR WHEAT-CULTIVATING SOILS IN TURKEY'S BORON- MINING ZONE
}

\author{
GULMEZOGLU, N. ${ }^{*}$ - AYTAC, Z. $^{2}-$ KUTLU, I. $^{3}-$ KULAN, E. G. ${ }^{2}-$ GOZUKARA, G. ${ }^{4}$ \\ ${ }^{1}$ Eskişehir Osmangazi University, Agricultural Faculty, Department of Soil Science and Plant \\ Nutrition, 26160, Eskişehir, Turkey. (phone: +90-222-324-2991; fax: +90-222-324-2990) \\ ${ }^{2}$ Eskişehir Osmangazi University, Agricultural Faculty, Department of Field Crops, 26160, \\ Eskişehir, Turkey. (phone: +90-222-324-2991; fax: +90-222-324-2990) \\ ${ }^{3}$ Eskişehir Osmangazi University, Agricultural Faculty, Department of Biosystem Engineering, \\ 26160, Eskişehir, Turkey. (phone: +90-222-324-2991; fax: +90-222-324-2990) \\ ${ }^{4}$ AkdeniziUniversity, Agricultural Faculty, Department of Soil Science and Plant Nutrition, \\ 07070, Antalya, Turkey. (phone: +90-0242-310-3748; fax: +90-242-227-4564) \\ *Corresponding author \\ e-mail:dgulmez@ogu.edu.tr \\ (Received 26 ${ }^{\text {th }}$ Jan 2017; accepted $23^{\text {rd }}$ Mar 2017)
}

\begin{abstract}
The mapping of boron (B) and beneficial heavy metals in the agricultural soils of mining zones is essential to evaluating the deficiencies and toxicity of those elements. Given its high annual production of boron, the Kirka Boron Mine (KBM) ranks among the largest mining complexes in Turkey. There, this research was conducted to determine the variation of some properties of soil with B and beneficial heavy metal ions (i.e., $\mathrm{Fe}, \mathrm{Zn}, \mathrm{Mn}$, and $\mathrm{Cu}$ ) according to great soil groups and to map their ions in wheatcultivating soils at different distances from KBM. Results showed that the $\mathrm{B}, \mathrm{Fe}, \mathrm{Cu}, \mathrm{Mn}$, and $\mathrm{Zn}$ contents of wheat-cultivated soils changed according to soil group and distance from KBM. The Fe content of soils decreased as the distance from KBM increased, and B content reached toxic values at a distance of 20-30 $\mathrm{km}$. $\mathrm{Mn}$ and $\mathrm{Zn}$ contents were low, though $\mathrm{B}$ and $\mathrm{Fe}$ contents were toxic, whereas $\mathrm{Cu}$ content was sufficient for wheat cultivation. Available B and beneficial heavy metal maps can be useful in confirming $\mathrm{B}$ and Fe pollution and in recommending fertiliser use in mining zones.
\end{abstract}

Keywords: great soil groups, fertiliser, Kırka, microelements, pollution

\section{Introduction}

Via special mechanisms, plants intake certain concentrations of beneficial heavy metal ions such as iron $(\mathrm{Fe})$, zinc $(\mathrm{Zn})$, copper $(\mathrm{Cu})$, and manganese $(\mathrm{Mn})$, as well as boron (B), a non-metal ion, from soil. When those ions appear in the soil in adequate amounts, they support the growth of crops by activating various enzymes and supporting cell metabolism (Broadley et al., 2012). Recent research (Nowack et al., 2008; Dwivedi et al., 2012; Gupta et al., 2015; Marathe and Sawant, 2016) has focused on the enrichment of nutrients with nutritional elements, most commonly Fe and Zn, to show that an overabundance of beneficial heavy metals and B in soil is toxic for plants (Alloway, 2013). Those ions appear in agricultural soils at inadequate or excessive concentrations due to industrial processes or the decomposition of the bedrock (Altan et al., 2016). The chief cause of those ions' appearance at excess levels in soil is their presence in mineral reserves found in geological bedrock. 
A staggering $72 \%$ of the world's boron reserves are in Turkey, among which the Kirka Boron Mine (KBM), given its high annual boron production, is the primary boron mine in the world (Helvac1 and Orti, 2004). Kirka is a neighbourhood of Seyitgazi in the district of Eskişehir in Central Anatolia, and though KBM bears a slightly hilly terrain, the agricultural area around Kırka is flat. Most of the cultivated area around the mining zone is composed of soil from the Brown Forest great soil group (BFGSGr) and Brown great soil group (BGSGr) (Anonymous, 2001). Wheat, as a major field crop cultivated in Central Anatolia, yields less (2.5 ton/ha) on average annually there than the wheat yield mean (5.0 ton/ha) of developed countries, and farmers in the region have complained that local boron mines make their fields unproductive (Çiçek ve Gence 2001). Research conducted to determine B toxicity in irrigation water, soil, and plants has shown that levels of B fluctuated in irrigation water, yet were not excessive, whereas the topsoil exhibited B pollution (Emiroğlu et al., 2010; Cetin et al., 2011). Although the amount of B found in the leaf tissue of crops in the area was not toxic, no research has shown the levels of beneficial heavy metal ions in the region's soils. In response, this study aimed to determine the variation of some soil properties with $\mathrm{B}$ and beneficial heavy metal ions (i.e., $\mathrm{Fe}, \mathrm{Zn}, \mathrm{Mn}$, and $\mathrm{Cu}$ ) according to great soil groups and different distances from KBM, to map those ions in wheat-cultivated soils, and to analyse any correlations among soil properties with B and grain yield.

\section{Materials and Methods}

\section{Site conditions}

Kurka is located at $39^{\circ} 16^{\prime} 59.9^{\prime \prime} \mathrm{N}$ and $30^{\circ} 31^{\prime} 59.9^{\prime \prime} \mathrm{E}$ at an altitude of $1,053 \mathrm{~m}$ and is $23 \mathrm{~km}$ from Seyitgazi in the Central Anatolia Region of Turkey (Figure 1). The study area covered approximately 156,884 ha, in a region with a hard, semiarid continental climate characterised by dry, hot summers and mostly cold, snowy winters. The total annual precipitation and monthly average temperature in the study area were $311.5 \mathrm{~mm}$ and $9.0^{\circ} \mathrm{C}$, respectively, for the last 30 years and $354 \mathrm{~mm}$ and $8.2^{\circ} \mathrm{C}$, also respectively, for 2011-2012's wheat cultivation season. The soils of the site mostly consisted of BFGSGr and BGSGr, classified per the US Department of Agriculture's (USDA) soil taxonomy system (Anonymous, 2001; Dinç et al., 2001).

\section{Sampling, analyses, and mapping}

Wheat cultivation fields were selected for soil sample collection because wheat is commonly grown in the region. Samples were taken at distances of 0-20, 20-30, and $30-40 \mathrm{~km}$ from KBM at a depth of 0-30 cm (180 points) in October 2011 before wheat sowing, and coordinates of the sampling points were measured using the Magellan Triton 400 GPS device (Magellan, North America). Samples included soils of the BFGSGr and BGSGr, as well as a few other soil types, determined by using soil taxonomy maps (Anonymous, 2001).

Samples were dried, sieved through a 2-mm stainless sieve, and subjected to analyses for $\mathrm{pH}$ (1:2.5 soil:water), electrical conductivity (EC, 1:2.5 soil:water), lime using a Scheibler calcimeter, organic matter using the Walkley-Black (1934) method, and texture using a hydrometer method. Plant-available beneficial heavy metal $(\mathrm{Fe}, \mathrm{Cu}, \mathrm{Mn}$, and $\mathrm{Zn}$ ) concentrations were assessed using methods described by Lindsay and Norwell (1978) via extraction with diethylenetriaminepentaacetic acid ( $\mathrm{pH} 7.3)$ with an atomic 
absorption spectrometer (Analytik Jena novAA 350, Jena, Germany). After samples were extracted with hot water, B was determined colourimetrically per the azomethine$\mathrm{H}$ method (Wolf, 1971). To gauge related elemental measurements, reference-available nutrients of agricultural soil that were certified reference material from the National Institute of Standards and Technology (Gaithersburg, MD, USA) were used. Readings of $\mathrm{pH}$, lime, (EC), organic matter, available in beneficial heavy metals (i.e., $\mathrm{Fe}, \mathrm{Cu}, \mathrm{Mn}$, and Zn), and B were classified according to Richards (1954), Ulgen and Yurtsever (1995), Smith and Weldon (1941), Linsay and Norwell (1978) and Berger and Trough (1940), respectively. Wheat grain yields from farmers' fields in the area (ton/ha) were determined by weighing after harvest.



Figure 1. Location map of the study area and sampling sites

The dataset representing the samples was evaluated according to descriptive statistics - namely, the minimum, maximum, mean, coefficient of variation (CV), skewness, and kurtosis coefficients - for each variable. CV, a significant indicator of change, in the samples was classified as low (<15\%), moderate (15-35\%), or high (>35\%) (Mulla and Mc Bratney, 2000), whereas skewness and kurtosis values indicated whether data could be generalised with normal distribution. The skewness coefficient revealed how data distribution strayed to the right or left of the norm; a negative result showed that the sample was below the average median, whereas a positive one indicated that it was above the median. If the mean was greater than the median, then the distribution skewed to the right (positive). If skewness is \pm 2 or less, then it was deemed normal. By contrast, the kurtosis coefficient showed the perpendicularity and oblateness of the normal distribution curve; a positive result meant that the slope was more perpendicular than normal, whereas a negative one indicated that the slope was more oblate than normal. To calculate skewness and kurtosis values, Equation 1 and Equation 2 were used, respectively (Stein, 2002): 


$$
\begin{aligned}
& \sum_{i=1}^{n} \frac{\left(y_{i}-\bar{y}\right)^{\mathrm{s} / n} / n}{s^{\mathrm{s}}} \\
& \sum_{i=1}^{n} \frac{\left(y_{i}-\bar{y}\right)^{4} / n}{s^{4}}
\end{aligned}
$$

in which $\bar{y}$ is the mean, $s$ is the standard deviation, and $n$ is the number of data points.

Relationships between samples with B content and wheat yield were determined by Pearson correlation analysis. All statistical analyses were performed using the SPSS 20.0 (IBM, Armonk, NY, USA). Spatial analyses of B, Zn, Mn, and Fe concentrations in the soils for mapping were performed randomly by inverse distance weighting using ArcGis 10.2 (ESRI Inc., Redlands, USA).

\section{Results}

\section{Physical and chemical properties of the soils}

Descriptive statistics describing some of the physical and chemical properties of samples from the site appear in Table 1 and 2. The vast majority of BGSGr soil had a clay texture $(60 \%)$, whereas that of BFGSGr had sandy (36\%). The $\mathrm{pH}$ classification of BGSGr ranged from neutral $(\mathrm{pH}>6.9)$ to slightly alkaline $(\mathrm{pH}<8.18)$, whereas that of BFGSGr was exclusively slightly alkaline ( $\mathrm{pH} 7.97-8.33)$; the $\mathrm{pH}$ of BFGSGr (8.12) was generally higher than that of BGSGr (7.75). The mean lime content of BGSGr samples $(11.4 \%)$ was far greater than that of BFGSGr $(5.7 \%)$; whereas the majority of BGSGr had moderate lime content (44\%), BFGSGr had less (35\%). The organic matter of BGSGr samples $(2.49 \%$, low) was less than that of BFGSGr (3.29\%, medium), and soil salt concentrations were quite low in both soil groups. The coefficients of skewness and kurtosis indicated that the soil properties were normally distributed; however, the $\mathrm{CV}$ of lime content in both group's soils was largely variable and ranged from $70.37 \%$ for BGSGr to $127.92 \%$ for BFGSGr (Table 1).

Table 1. Descriptive statistics of texture (\%), $\mathrm{pH}$, lime $\left(\mathrm{CaCO}_{3}\right)(\%)$, organic matter $(\mathrm{OM})$ $(\%)$ and $E C(d S / m)$ of brown forest and brown great soil groups

\begin{tabular}{llccccccc}
\hline & & \multicolumn{3}{c}{ Texture } & \multirow{2}{*}{ pH } & Lime & \multirow{2}{*}{ OM } & \multirow{2}{*}{ EC } \\
\cline { 2 - 8 } Great soil groups & Parameter & Sand & Silt & Clay & & & & \\
\hline \multirow{5}{*}{ Brown-Forest } & Min. & 29.30 & 4.90 & 14.20 & 7.97 & 0.45 & 2.21 & 0.17 \\
& Max. & 78.70 & 24.50 & 62.10 & 8.33 & 28.00 & 4.80 & 0.44 \\
& Mean & 45.64 & 17.40 & 36.96 & 8.12 & 5.70 & 3.29 & 0.24 \\
\cline { 2 - 8 } & CV\% & 27.85 & 28.02 & 28.65 & 1.37 & 127.92 & 23.42 & 26.48 \\
& Skewness & 1.28 & -1.12 & -0.07 & 0.24 & 2.01 & 0.28 & 1.73 \\
& Kurtosis & 1.46 & 1.10 & 0.33 & -1.28 & 3.95 & -1.05 & 3.99 \\
\hline \multirow{5}{*}{ Brown } & Min. & 27.40 & 11.00 & 17.60 & 6.90 & 1.13 & 1.33 & 0.17 \\
& Max. & 58.60 & 47.70 & 61.60 & 8.18 & 27.40 & 4.75 & 0.64 \\
& Mean & 37.85 & 21.90 & 40.27 & 7.75 & 11.44 & 2.49 & 0.30 \\
\hline & CV\% & 20.98 & 50.57 & 36.19 & 4.96 & 70.37 & 28.34 & 33.12 \\
& Skewness & 0.85 & 1.40 & -0.26 & -0.94 & 0.75 & 1.34 & 1.74 \\
& Kurtosis & 0.97 & 0.88 & -1.18 & -0.25 & -0.53 & 3.29 & 3.91 \\
\hline
\end{tabular}


In the evaluation by distance from KBM, $52 \%$ of samples were sandy at up to $20 \mathrm{~km}$. Moreover, $47 \%$ of the samples were clay between 20 and $30 \mathrm{~km}$, whereas $43 \%$ were clay between 30 and $40 \mathrm{~km}$. The mean lime content, $\mathrm{pH}$, and $\mathrm{EC}$ values of the samples increased with distance from KBM up to $40 \mathrm{~km}$ (Table 2). However, soil salinity $(<4$ $\mathrm{dS} / \mathrm{m}$ ) was not high for wheat cultivation. Approximately $40 \%$ of the samples were low in lime up to $20 \mathrm{~km}$, whereas $33 \%$ and $53 \%$ of the samples had moderate lime at 20-30 $\mathrm{km}$ and 30-40 km, respectively. Approximately $40 \%$ of the samples also had high organic matter up to $20 \mathrm{~km}, 67 \%$ low organic matter at $20-30 \mathrm{~km}$, and $60 \%$ moderate organic matter at $30-40 \mathrm{~km}$. the $\mathrm{CV}$ of lime values of samples decreased with distance from KBM (Table 2).

Table 2. Descriptive statistics of texture (\%), $\mathrm{pH}$, lime $\left(\mathrm{CaCO}_{3}\right)(\%)$, organic matter $(\mathrm{OM})$ $(\%)$ and $E C(\mathrm{dS} / \mathrm{m})$ of distance $(\mathrm{km})$ from Kirka Boron Mine

\begin{tabular}{|c|c|c|c|c|c|c|c|c|}
\hline \multirow[b]{2}{*}{ Distance } & \multirow[b]{2}{*}{ Parameter } & \multicolumn{3}{|c|}{ Texture } & \multirow{2}{*}{$\mathrm{pH}$} & \multirow{2}{*}{ Lime } & \multirow{2}{*}{$\mathrm{OM}$} & \multirow{2}{*}{$\mathrm{EC}$} \\
\hline & & Sand & Silt & Clay & & & & \\
\hline \multirow{6}{*}{$0-20$} & Min. & 30.40 & 4.90 & 14.20 & 6.90 & 0.45 & 2.21 & 0.17 \\
\hline & Max. & 78.70 & 47.70 & 42.60 & 8.18 & 28.00 & 4.80 & 0.44 \\
\hline & Mean & 51.70 & 23.18 & 25.14 & 7.70 & 5.98 & 3.38 & 0.24 \\
\hline & $\mathrm{CV} \%$ & 25.03 & 56.84 & 28.82 & 5.50 & 137.24 & 24.00 & 29.52 \\
\hline & Skewne & 0.73 & 0.67 & 0.83 & -0.62 & 1.87 & 0.01 & 1.79 \\
\hline & Kurtos & 0.71 & -0.50 & 1.00 & -1.03 & 2.94 & -1.08 & 3.68 \\
\hline \multirow{6}{*}{$20-30$} & Min. & 27.40 & 11.00 & 24.70 & 7.67 & 0.82 & 1.33 & 0.17 \\
\hline & Max. & 58.60 & 21.20 & 61.60 & 8.33 & 25.55 & 4.04 & 0.31 \\
\hline & Mean & 36.96 & 16.16 & 46.90 & 8.04 & 9.28 & 2.38 & 0.24 \\
\hline & CV\% & 22.05 & 18.23 & 21.10 & 2.02 & 86.91 & 28.22 & 15.34 \\
\hline & Skewness & 1.24 & -0.39 & -0.39 & -0.50 & 0.96 & 0.84 & 0.27 \\
\hline & Kurtosis & 2.41 & -0.37 & -0.38 & 1.02 & -0.44 & 1.44 & 0.01 \\
\hline \multirow{6}{*}{$30-40$} & Min. & 29.30 & 8.60 & 33.50 & 7.97 & 1.13 & 1.94 & 0.23 \\
\hline & Max. & 49.30 & 23.30 & 62.10 & 8.28 & 27.40 & 4.75 & 0.64 \\
\hline & Mean & 37.89 & 18.89 & 43.25 & 8.12 & 11.41 & 2.78 & 0.35 \\
\hline & $\mathrm{CV} \%$ & 12.72 & 19.84 & 15.97 & 1.33 & 68.45 & 25.65 & 30.56 \\
\hline & Skewn & 0.72 & -1.55 & 1.21 & -0.01 & 1.07 & 1.60 & 1.52 \\
\hline & Kurtosis & 1.25 & 3.03 & 3.31 & -1.51 & 0.65 & 3.42 & 2.89 \\
\hline
\end{tabular}

\section{Microelement contents of the soils}

The descriptive statistics of the $\mathrm{B}, \mathrm{Fe}, \mathrm{Cu}, \mathrm{Mn}$, and $\mathrm{Zn}$ contents of both soil groups and the distance from KBM appear in Tables 3 and 4. The available B and beneficial heavy metal maps of the samples by distance from KBM appear in Figure 2. The B, Fe, $\mathrm{Cu}, \mathrm{Mn}$, and $\mathrm{Zn}$ contents of wheat-cultivated soils changed depending on the soil group and distance from KBM. The maximum $(4.26 \mathrm{mg} / \mathrm{kg})$ and mean $(1.48 \mathrm{mg} / \mathrm{kg})$ of B content of samples were greater in BGSGr than in BFGSGr (Table 3). BFGSGr samples were rich with $\mathrm{Fe}$ and $\mathrm{Mn}$, and high $\mathrm{B}$ and $\mathrm{Zn}$ contents were also detected in BGSGr samples. B and beneficial heavy metal contents except for $\mathrm{Cu}(\mathrm{CV}<35 \%)$ showed high variations in both soil groups. The Fe content (3.35) of BFGSGr and Zn content (2.29) of BGSGr were also greater than the acceptable skewness limit $( \pm 2)$, as Table 3 shows. 
Table 3. Descriptive statistic of B ( $m g / \mathrm{kg}), \mathrm{Fe}(\mathrm{mg} / \mathrm{kg}), \mathrm{Mn}(\mathrm{mg} / \mathrm{kg}), \mathrm{Cu}(\mathrm{mg} / \mathrm{kg}), \mathrm{Zn}(\mathrm{mg} / \mathrm{kg})$ and grain yield (ton/ha) of brown forest and brown great soil groups

\begin{tabular}{llllllll}
\hline Great soil groups & Parameter & $\mathrm{B}$ & $\mathrm{Fe}$ & $\mathrm{Mn}$ & $\mathrm{Cu}$ & $\mathrm{Zn}$ & Grain yield \\
\hline \multirow{5}{*}{ Brown-Forest } & Min. & 0.63 & 2.34 & 2.47 & 0.42 & 0.17 & 1.80 \\
& Max. & 2.26 & 22.78 & 48.10 & 1.89 & 1.30 & 4.80 \\
& Mean & 1.03 & 5.99 & 16.14 & 1.21 & 0.44 & 3.20 \\
\cline { 2 - 8 } & CV\% & 36.29 & 72.42 & 86.46 & 31.47 & 73.02 & 26.12 \\
& Skewness & 1.96 & 3.35 & 0.98 & 0.13 & 1.99 & 0.21 \\
& Kurtosis & 5.64 & 12.86 & -0.14 & -0.09 & 3.40 & -0.79 \\
\hline \multirow{5}{*}{ Brown } & Min. & 0.41 & 1.61 & 0.15 & 0.57 & 0.14 & 2.50 \\
& Max. & 4.26 & 6.02 & 37.70 & 1.82 & 2.8 & 5.00 \\
& Mean & 1.48 & 3.25 & 10.43 & 1.22 & 0.58 & 3.58 \\
\cline { 2 - 7 } & CV\% & 75.71 & 36.92 & 85.90 & 27.10 & 119.86 & 20.22 \\
& Skewness & 1.45 & 1.02 & 1.98 & -0.22 & 2.29 & 0.50 \\
& Kurtosis & 1.13 & 0.15 & 4.43 & -0.78 & 4.46 & -0.60 \\
\hline
\end{tabular}

Table 4. Descriptive statistic of B $(\mathrm{mg} / \mathrm{kg}), \mathrm{Fe}(\mathrm{mg} / \mathrm{kg}), \mathrm{Mn}(\mathrm{mg} / \mathrm{kg}), \mathrm{Cu}(\mathrm{mg} / \mathrm{kg}), \mathrm{Zn}(\mathrm{mg} / \mathrm{kg})$ and grain yield (ton/ha) of distance $(\mathrm{km})$ from Kirka Boron Mine

\begin{tabular}{llllllll}
\hline Distance & Parameter & $\mathrm{B}$ & $\mathrm{Fe}$ & $\mathrm{Mn}$ & $\mathrm{Cu}$ & $\mathrm{Zn}$ & Grain yield \\
\hline \multirow{5}{*}{$10-20$} & Min. & 0.63 & 2.34 & 2.73 & 0.42 & 0.17 & 3.00 \\
& Max. & 2.26 & 22.78 & 48.10 & 1.89 & 1.30 & 4.80 \\
& Mean & 1.08 & 5.94 & 17.16 & 1.16 & 0.47 & 3.61 \\
\cline { 2 - 8 } & CV\% & 37.94 & 82.32 & 88.51 & 35.66 & 75.58 & 16.63 \\
& Skewness & 1.75 & 3.30 & 0.91 & 0.38 & 1.77 & 0.55 \\
& Kurtosis & 4.49 & 11.78 & -0.56 & -0.16 & 2.22 & -0.81 \\
\hline \multirow{3}{*}{$20-30$} & Min. & 0.41 & 1.61 & 2.47 & 0.57 & 0.14 & 2.10 \\
& Max. & 4.13 & 9.82 & 24.94 & 1.69 & 2.18 & 4.70 \\
& Mean & 1.49 & 4.27 & 9.75 & 1.09 & 0.46 & 2.84 \\
\cline { 2 - 8 } & CV\% & 81.52 & 48.13 & 65.22 & 26.24 & 110.67 & 22.89 \\
& Skewness & 1.09 & 1.44 & 1.57 & 0.21 & 3.04 & 1.64 \\
& Kurtosis & -0.10 & 2.90 & 2.06 & 0.16 & 10.04 & 4.17 \\
\hline \multirow{3}{*}{$30-40$} & Min. & 0.57 & 2.22 & 0.15 & 1.16 & 0.19 & 3.00 \\
& Max. & 4.26 & 6.02 & 37.70 & 1.68 & 1.98 & 5.00 \\
& Mean & 1.27 & 3.19 & 12.00 & 1.43 & 0.45 & 3.90 \\
\cline { 2 - 7 } & CV\% & 69.21 & 40.79 & 93.56 & 10.27 & 103.82 & 15.66 \\
& Skewness & 3.23 & 1.52 & 1.38 & -0.31 & 2.91 & 0.42 \\
& Kurtosis & 11.18 & 1.09 & 1.54 & 0.04 & 8.72 & -0.23 \\
\hline
\end{tabular}




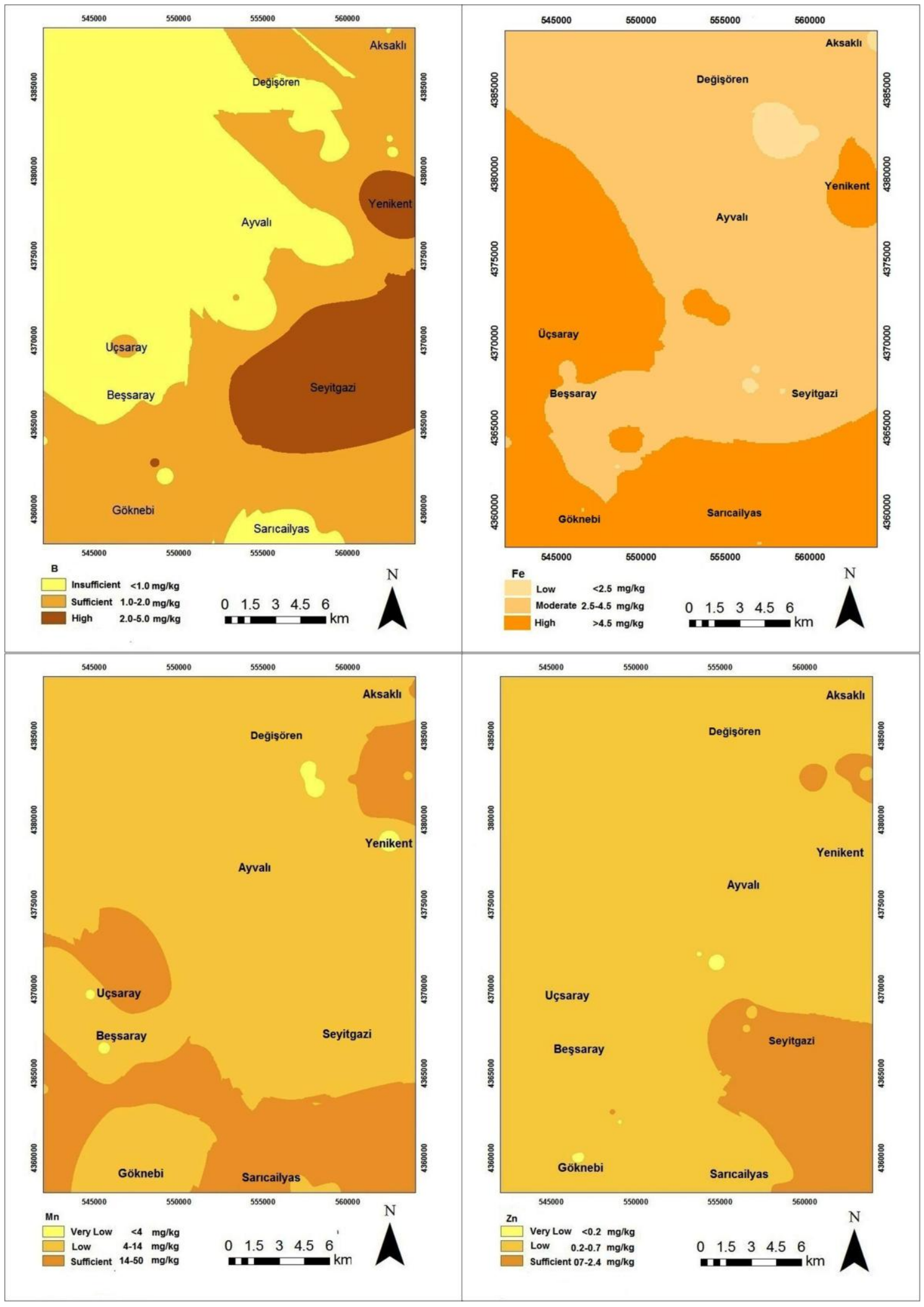

Figure 2. Spatial distribution maps of avalible B, Fe, Mn and Zn concentrations of samples by distance from Kırka Boron Mine 
As the distance from KBM increased, so did B levels in the soil (Table 4, Figure 2). Whereas Fe content decreased with distance, mean $\mathrm{Zn}$ content was nearly the same at each distance. $\mathrm{Mn}$ and $\mathrm{Cu}$ contents demonstrated no regular relation to distance. Although only slight variation in $\mathrm{Cu}$ content $(\mathrm{CV}<35 \%)$ appeared at different distances from KBM, all other elements showed high CV. Deviations from the normal distribution of skewness coefficients were as follows: up to $20 \mathrm{~km}$ for $\mathrm{Fe}$ (3.30), between 20 and $30 \mathrm{~km}$ for $\mathrm{Zn}$ (3.04) and between 30 to $40 \mathrm{~km}$ for B (3.23) and $\mathrm{Zn}$ (2.91), as shown in Table 4.

Wheat yield varied from 1.8 to 4.8 ton/ha in BFGSGr soil, yet changed between 2.5 and 5.0 ton/ha in BGSGr soil. Understandably, yield showed moderate variation, as supported with CV values of roughly $26 \%$ in BFGSGr and $20 \%$ in BGSGr (Table 3). The mean yield of wheat was $3.61 \mathrm{ton} / \mathrm{ha}$ up to $20 \mathrm{~km}, 2.84 \mathrm{ton} / \mathrm{ha}$ between 20 and 30 $\mathrm{km}$, and $3.9 \mathrm{ton} / \mathrm{ha}$ between 30 to $40 \mathrm{~km}$ from KBM. The CV of the wheat yield by distance showed a mid-level change, and the values distributed normally regarding the skewness coefficient (Table 4).

\section{Correlations between soil physical and chemical properties with $B$ and wheat yield}

Significant positive and negative relationships between soil physical and chemical properties with B and wheat yield according to soil group and distance from KBM appear in Table 5. In BGSGr soil, a positive correlation between B and $\mathrm{Zn}$ and a negative one between B and lime emerged. In that soil group, though the effects of sand and lime contents in soil on yield were negative, the $\mathrm{Cu}$ and clay contents of soil affected the yield positively. In BFGSGr soil, a significant, positive correlation emerged between B with lime and organic matter, though a negative one occurred between B and $\mathrm{Cu}$. In that soil group, increasing amounts of silt negatively affected yield, whereas increasing amounts of clay benefitted it, as it did in BGSGr soil (Table 5).

Table 5. Correlation coefficients between soil properties with $B$ and wheat yield

\begin{tabular}{|c|c|c|c|c|c|}
\hline \multirow{2}{*}{ Relationships } & \multicolumn{2}{|c|}{ Great Soil Groups } & \multicolumn{3}{|c|}{ Distance $(\mathrm{km})$} \\
\hline & Brown & Brown-Forest & $0-20$ & $20-30$ & $30-40$ \\
\hline $\mathrm{B}-\mathrm{Fe}$ & - & - & - & - & $0.567^{*}$ \\
\hline $\mathrm{B}-\mathrm{Cu}$ & - & $-0.492^{*}$ & $-0.484^{*}$ & - & - \\
\hline $\mathrm{B}-\mathrm{Zn}$ & $0.36^{*}$ & - & - & $0.741^{* *}$ & - \\
\hline B-Clay & - & - & $-0.460^{*}$ & $0.693^{* *}$ & - \\
\hline B-Lime & $-0.401^{*}$ & $0.585^{* *}$ & $0.637^{* *}$ & - & - \\
\hline B-OM & - & $0.490^{*}$ & - & - & - \\
\hline Yield-B & - & - & - & $0.600^{* *}$ & - \\
\hline Yield-Fe & - & - & - & $-0.515^{*}$ & - \\
\hline Yield-Cu & $0.530^{* *}$ & - & - & - & - \\
\hline Yield-Sand & $-0.650^{* *}$ & - & - & - & - \\
\hline Yield-Silt & - & $-0.646^{* *}$ & $0.499^{*}$ & $-0.599^{* *}$ & - \\
\hline Yield-Clay & $0.640^{* *}$ & $0.538^{* *}$ & - & $0.819^{* *}$ & - \\
\hline Yield-Lime & $-0.434^{*}$ & - & - & - & $-0.611^{* *}$ \\
\hline
\end{tabular}

*Significant at $\mathrm{p}<0.05, * *$ Significant at $\mathrm{p}<0.01$. 
In the assessment based on distance, negative correlations between $\mathrm{B}$ with $\mathrm{Cu}$ and clay surfaced at up to $20 \mathrm{~km}$ away, whereas a positive correlation emerged between B and lime. Silt content and yield correlated positively at up to $20 \mathrm{~km}$ and negatively between 20 and $30 \mathrm{~km}$. By contrast, positive correlations between B with clay and $\mathrm{Zn}$ in the area appeared between 20 and $30 \mathrm{~km}$. Correlations between yield with B and clay were positive between 20 and $30 \mathrm{~km}$, whereas yield with Fe was negative. Between 30 and $40 \mathrm{~km}$, a positive correlation between $\mathrm{B}$ with $\mathrm{Fe}$ and negative correlation to lime with yield was observed (Table 5).

\section{Discussion}

The $\mathrm{pH}$, sand, and organic matter contents of BFGSGr soils was high, whereas BGSGr soils contained high amounts of clay, lime, and EC. According to the USDA soil taxonomy, BGSGr belongs to light-coloured soils in arid regions' subordo of zonal soils, whereas BFGSGr belongs to the calcimorphic subordo of intrazonal soils (Dinç et al., 2001). In general, BGSGr soils consist of 1.0-1.5\% organic matter, lime, and clay and are alkaline. BFGSGr soils consist of moderate organic matter with low-level clay and less lime content than BGSGr (Bayramin, 2015). Most soil up to $20 \mathrm{~km}$ from KBM was sandy, after which it became clay at $20-40 \mathrm{~km}$. The EC, $\mathrm{pH}$, and lime content of the soils near KBM were low, whereas organic matter content was high. The soil properties of BFGSGr and BGSGr were compatible with general characteristics since all soil properties examined were normally distributed (skewness coefficient $\leq 2$ ) (Webster, 2001).

Low B content $(<1 \mathrm{mg} / \mathrm{kg}$ ) was found in 55\% of BFGSGr samples and $40 \%$ of BGSGr samples. However, high B content ( $>2 \mathrm{mg} / \mathrm{kg}$ ) was seen in $24 \%$ of BGSGr soils and in values of $2-5 \mathrm{mg} / \mathrm{kg}$ in the area $20-30 \mathrm{~km}$ from KBM (Figure 2). Important factors that decrease the benefits of $\mathrm{B}$ in the soil are $\mathrm{pH}$, clay minerals, humidity, lime, oxides, and organic matter (Broadley et al., 2012). A previous study reported that B content in the irrigated soil of the region was $0.08-3.40 \mathrm{mg} / \mathrm{kg}$, in a fluctuation due to the study site's proximity to KBM (Cetin et al., 2011). Emiroğlu et al. (2010) also determined that the $\mathrm{B}$ content of the irrigation water was greater than the standards of the Turkish Environmental Guidelines $(>1 \mathrm{mg} / \mathrm{L})$ and counterparts in Europe (>0.6 $\mathrm{mg} / \mathrm{L}$ ).

Whereas $5 \%$ of BFGSGr samples had low Fe content $(<2.5 \mathrm{mg} / \mathrm{kg}), 65 \%$ had high Fe content $(>4.5 \mathrm{mg} / \mathrm{kg})$. However, $40 \%$ of BGSGr had low Fe content and $24 \%$ high $\mathrm{Fe}$ content. BGSGr soil contained Fe content toxic to plants, though the Fe content of soils up to $40 \mathrm{~km}$ from KBM decreased. Taban et al. (1997) and Eyüpoğlu et al. (1998) found that $73 \%$ of soils in Turkey had high Fe content, which the current results corroborate.

Approximately $10 \%$ of BFGSGr soil had low Mn content and 50\% sufficient in terms of $\mathrm{Mn}$, whereas $75 \%$ were very low and $15 \%$ sufficient in terms of $\mathrm{Zn}$ content. With respect to the Mn content of BGSGr, $16 \%$ of the soils were very low and $64 \%$ sufficient. Regarding the $\mathrm{Zn}$ content of BGSGr soils, $68 \%$ were very low and $16 \%$ sufficient. For both soil groups and at all distances, $\mathrm{Cu}$ content was sufficient. $\mathrm{Mn}$ content was sufficient up to $20 \mathrm{~km}$, yet low at $20-40 \mathrm{~km}$. The mean $\mathrm{Zn}$ content of soils did not change depending on distance (Figure 2). Eyüpoğlu (1999) indicated Mn deficiency of $44 \%$ in Turkish soils, especially due to the high $\mathrm{pH}$ values. The availability of $\mathrm{Mn}$ decreases due to the high oxidation of $\mathrm{Mn}^{+2}$ to $\mathrm{Mn}^{+4}$ as a result of high bacterial activity occurring at around 6.5 and $8.0 \mathrm{pH}$. Moreover, $\mathrm{Mn}$ is affected by 
not only $\mathrm{pH}$, but also $\mathrm{Ca}, \mathrm{Mg}, \mathrm{Fe}, \mathrm{Zn}$, and $\mathrm{NH}_{4}$ ions at increased concentrations (Sparrow and Uren, 2014). Available $\mathrm{Zn}$ concentration changes between 0.1 and 0.6 $\mathrm{mg} / \mathrm{kg}$ in soils of Central Anatolia given the presence of lime, high $\mathrm{pH}$ levels, low organic matter, and low precipitation ( $<300 \mathrm{~mm} /$ year) (Çakmak et al., 1996).

Wheat yields varied according to soil groups and distance from KBM, and those differences could be due to the variation of soil features along with cultivar differences and cultural activities such as irrigation and fertilisation.

It is critical to determine correlations among texture, lime, organic matter, and $\mathrm{B}, \mathrm{Fe}$, $\mathrm{Zn}, \mathrm{Cu}$, and $\mathrm{Mn}$ contents in soils with wheat yields. Reportedly, if the clay content of soil is high, then wheat yield is better. The high water-holding capacity of clay soil could provide a significant increase in wheat yield (Nouri et al., 2016). The soil should have less than $1 \mathrm{mg} / \mathrm{kg}$ of B, $5 \mathrm{mg} / \mathrm{kg}$ of Fe, $1 \mathrm{mg} / \mathrm{kg}$ of $\mathrm{Mn}, 0.5 \mathrm{mg} / \mathrm{kg}$ of $\mathrm{Zn}$, and 0.5 $\mathrm{mg} / \mathrm{kg}$ of $\mathrm{Cu}$, since wheat cultivation requires fertilisation with these minerals (Jacobsen et al., 2003; Wang et al., 2016). By contrast, other studies have reported that Zn application to soil increases wheat yield by $260 \%$, especially where $\mathrm{Zn}$ content in the Central Anatolian Region is less than $0.5 \mathrm{mg} / \mathrm{kg}$ (Y1lmaz et al., 1997).

In sum, the mean of wheat yield and B and Zn contents in BGSGr soils, as well as mean Fe and Mn contents in BFGSGr soils, were high. Fe content in the soils decreased as the distance from KBM increased, and B content reached toxic values at $20-30 \mathrm{~km}$. $\mathrm{Mn}$ and $\mathrm{Zn}$ contents were found to be low, $\mathrm{B}$ and $\mathrm{Fe}$ contents were toxic, and $\mathrm{Cu}$ content was sufficient for wheat cultivation in the examined soils. Available B and beneficial heavy metal mapping might be useful to confirm $\mathrm{B}$ and $\mathrm{Fe}$ pollution or recommend the use of fertiliser in the mining zone.

Acknowledgements. This research supported by the Scientific Research Projects Commission of Eskisehir Osmangazi University (project no: 201123015) is fully acknowledged. The authors would like to give their sincere thanks to Muazzez GUNAY from Eskisehir Directorate of Provincial Food Agriculture and Livestock.

\section{REFERENCES}

[1] Alloway, B.J. (2013): Sources of heavy metals and metalloids in soils.- In: Alloway, B.J. (ed.) Heavy Metals in Soils. Trace Metals and Metalloids in Soils and their Bioavailability. Springer, Dordrecht, pp. 11-50.

[2] Altan, M., Ayyıldı, O., Malkoc, S., Yazıcı, B., Koparal, A.S. (2016): Mapping of heavy metal contamination characteristics using CIAPRG methodology. - Applied Ecology and Environmental Research 14(2): 433-446.

[3] Anonymous (2001): Lands of Eskisehir Province (Eskişehir İli Arazi Varlı̆̆ı). T.C. Başbakanlık Köy Hizmetleri Genel Müdürlüğü Yayınları, Rp. No: 26.

[4] Bayramin, I. (2015): American soil classification system and soil taxonomy (Amerikan toprak sınıflama sistemi ve toprak taksonomisi). - In: Şenol, S., Küsek, G., Sarı, M. and Y. Kurucu (eds) Soil Survey Mapping Manuel (Toprak Etüd Haritalama El Kitabı). pp: 365-475, Ankara.

[5] Berger, K. C., Truog, E. (1940): Boron deficiencies as revealed by plant and soil tests. - J. Am. Soc. Agron. 32: 297-301.

[6] Broadley, M., Brown, P., Cakmak, I., Rengel, Z., Zhao, F. (2012): Function of nutrients: Micronutrients-Boron.- In: Marschner, P. (ed) Marschner's Mineral Nutrition of Higher Plants. Elsevier, Oxford, UK. pp. 249-269. 
[7] Broadley, M., Brown, P., Cakmak, I., Ma, J. F., Rengel, Z. and Zhao, F. (2012) Beneficial elements.- In: Marschner, P. (ed) Marschner's Mineral Nutrition of Higher Plants. Elsevier, Oxford, UK. pp. 232-239.

[8] Cakmak, I., Yilmaz, A., Ekiz, H., Torun, B., Erenoglu, B., Braun, H. J. (1996): Zinc deficiency as a critical nutritional problem in wheat production in Central Anatolia. Plant Soil 180:165- 172.

[9] Cetin, O., Uygan, D., Yalcin, G. (2011): Impacts of boron-affected water in boron-mining catchment area on soil and crops.- Journal of Environmental Protection and Ecology 12(4A): 2028-2037.

[10] Çiçek, A., Gence, S. (2001): Investigation of agricultural crops grown in Kırka-Seyitgazi (Eskişehir) region and boron accumulation in the soil (Kırka-Seyitgazi (Eskişehir) yöresinde yetiştirilen tarım ürünleri ve topraktaki bor birikiminin araştırılması).- Ulusal Sanayi-Çevre Sempozyumu ve Sergisi, 25-27 Nisan 2001, Mersin, Bildiriler Kitabı, 600608.

[11] Dinç, U., Şenol, S., Kapur, S., Cangir, C., Atalay, I. (2001): Turkish Soils (Türkiye Toprakları). Çukurova Üniversitesi Ziraat Fakültesi Yayınları No: 51, Adana.

[12] Dwivedi, S. L., Sahrawat, K.L., Rai, K.N., Blair, M.W., Andersson, M.S., Pfeiffer, W.H. (2012): Nutritionally enhanced staple food crops. - Plant Breeding Reviews 36: 169-291.

[13] Emiroglu, O., Çiçek, A., Arslan, N., Aksan, S., Rüzgar, M. (2010): Boron concentration in water, sediment and different organisms around large borate deposits of Turkey. Bull. Environ. Contam. Toxicol. 84:427-431. DOI 10.1007/s00128-010-9961-8.

[14] Eyüpoğlu, F., Kurucu, N., Talaz, S. (1998): General status of avaible micro elements (Fe, $\mathrm{Cu}, \mathrm{Zn}, \mathrm{Mn}$ ) of Turkish soils (Türkiye topraklarının bitkiye yarayışlı bazı mikroelementler ( $\mathrm{Fe}, \mathrm{Cu}, \mathrm{Zn}, \mathrm{Mn}$ ) bakımından genel durumu). T.C. Başbakanlık KHGM Toprak Gübre Araştırma Enstütüsü.

[15] Eyüpoğlu, F. (1999): The Soil Fertility of Turkey (Türkiye Topraklarının Verimlilik Durumu). Toprak ve Gübre Araştırma Enstitüsü Yayınları Genel Yayın No: 220 Teknik Yayin No: T-67, Ankara.

[16] Gupta, H.S, Hossain, F., Nepolean, T., Vignesh, M., Mallikarjuna, M.G. (2015): Understanding genetic and molecular bases of $\mathrm{Fe}$ and $\mathrm{Zn}$ accumulation towards development of micronutrient-enriched maize. - In: Rakshit et al. (eds.), Nutrient Use Efficiency: from Basics to Advances, Springer India, pp. 255- 282. DOI 10.1007/978-81322-2169-2_17.

[17] Helvac1, C., Orti, F. (2004): Zoning in the Kırka borate deposit, western Turkey: primary evaporitic fractionation or diagenetic modifications. - Can. Mineral. 42 (4): 1179-1204.

[18] Jacobsen, J., Jackson, G., Jones, C. (2003): Fertilizer Guidelines for Montana Crops. Montana Agricultural Experiment Station, Bozeman, Montana. EB 161.

[19] Lindsay, W.L., Norvell, W.A. (1978): Development of a DTPA soil Test for Zn, Fe, Mn and $\mathrm{Cu}$. - Soil Sci. Soc. Amer. Proc. 42: 421-428.

[20] Marathe, R. B., Sawant, C. P. (2016): Morphological, nutritional and mineralogical status of soil samples collected from shirud site of shahada tehsil of nandurbar district. International Journal of Science and Research 5(12): 1165-1169.

[21] Mulla, D.J., McBratney, A.B. (2000): Soil spatial variability, A-321-A-351, In: Malcolm E. S. (ed) Handbook of Soil Science, Crs Pres.

[22] Nouri, M., Homaee, M., Bannayan, M., Hoogenboom, G. (2016): Towards modeling soil texture-specific sensitivity of wheat yield and water balance to climatic changes. Agricultural Water Management 177: 248-263.

[23] Nowack, B., Schwyzer, I., Schulin, R. (2008): Uptake of Zn and Fe by wheat (Triticum aestivum var. Greina) and transfer to the grains in the presence of chelating agents (Ethylenediaminedisuccinic Acid and Ethylenediaminetetraacetic Acid). - J. Agric. Food Chem., 56: 4643-4649. 
[24] Richards, L.A. Ed. (1954): Diagnosis and Improvement of Saline and Alkali Soils. US Salinity Lab., United States Department of Agriculture Handbook 60:94. California, USA.

[25] Smith, H.W., Weldon, M.D. (1941): A comparison of some methods for the determination of soil organic matter. - Soil Science Society American Proceeding 5: 177182.

[26] Sparrow. L. A., Uren N.C. (2014): Manganese oxidation and reduction in soils: effects of temperature, water potential, $\mathrm{pH}$ and their interactions. - Soil Research 52(5): 483-494 http://dx.doi.org/10.1071/SR13159

[27] Stein, A. (2002): Some basic elements of statistic. - In: Stein, A., Van Der Meen, F., Gorte, B. (eds) Spatial Statistic for Remote Sensing. Kluwer Academic Publishers, p. 13.

[28] Taban, S., Alpaslan, M., Hashemi A.G., Eken, D. (1997): Some physical and chemical properties of rice cultivated soils in Central Anatolia (Orta Anadolu'da çeltik tarımı yapılan toprakların bazı fiziksel ve kimyasal özellikleri). - Pamukkale Üniv. Mühendislik Fak. Mühendislik Bilimleri Dergisi. 3(3): 457-466.

[29] Ülgen, N., Yurtsever, N. (1995): Fertilizer and Fertilization Guide of Turkey (Türkiye Gübre ve Gübreleme Rehberi). Toprak ve Gübre Araştırma Enstitüsü Yayınları, Genel yayın No: 209, Teknik Yayınlar No: T.66, Ankara.

[30] Walkley, A., Black, I.A. (1934): An examination of the degtjareff method for determining soil organic matter, and a proposed modification of the chromic acid titration method. Soil Sci. 37: 29-38.

[31] Wang, F., Wang, Z., Kou, C., Ma, Z., Zhao, D. (2016): Responses of wheat yield, macroand micro-nutrients, and heavy metals in soil and wheat following the application of manure compost on the North China Plain. - PLoS ONE 11(1): e0146453. doi:10.1371/journal.pone. 0146453

[32] Webster, R. (2001): Statistics to support soil research and their presentation. - European Journal of Soil Science 52: 331-340.

[33] Wolf, B. (1971): The determination of boron in soil extracts, plant materials, compost, manure, water, and nutrient solutions. - Commu. Soil Sci. Plant Anal. 2: 363-374.

[34] Yilmaz, A., Ekiz, H., Torun, B., Gültekin, I., Karanlı, S., Bagcı, S.A. and Cakmak, I. (1997): Different zinc application methods on grain yield, and zinc concentrations in wheat grown on zinc-deficient calcareous soils in Central Anatolia. - J. Plant Nutr. 20:461-471. 